\title{
Gautavík - a trading site in Iceland re-examined
}

\author{
NATASCHA MEHLER, GUĐMUNDUR ÓLAFSSON, \\ BART HOLTERMAN, JORIS COOLEN, \\ RAGNAR EDVARDSSON, TORBJÖRN BRORSSON
}

\begin{abstract}
Mehler, N., Ólafsson, G., Holterman, B., Coolen, J., Edvardsson, R., Brorsson, T. 2019. Gautavík-a trading site in Iceland re-examined. AmS-Skrifter 27, 259-275, Stavanger, ISSN 0800-0816, ISBN 978-82-7760-183-0.

Gautavík is a well-known archaeological site on the east coast of Iceland. It was partially excavated in 1979 and interpreted as a seasonal occupied trading site, abandoned shortly after $c$. 1500. However, recent archaeological research on the excavated ceramics, which hitherto had not been studied in detail, raised doubts about the interpretation regarding the dating and function of the site. New research was then initiated that included an investigation of written documents in the archives of Bremen, Hamburg, and Copenhagen, pertaining to the trade with Iceland during the sixteenth century. On the basis of the new results presented here we now interpret Gautavík to have been a trading harbour that also included a farm, at least periodically, occupied from the late twelfth century, at the latest, until shortly before 1600. Gautavík was a place of supra-regional importance, being the main port of entry in Berufjörður during the medieval period. In the sixteenth century, however, Gautavík lost its importance. This was a period of intensive trade of German merchants with Iceland, and after Bremen and Hamburg merchants established Djúpivogur and Fýluvogur at the entrance of the fjord $c$. 1570, both gradually superseded Gautavík, such that shortly before 1600 trade was no longer conducted there.
\end{abstract}

Natascha Mehler, Deutsches Schifffahrtsmuseum, Leibniz-Institut für maritime Geschichte, Hans-Scharoun-Platz 1, D-27568 BREMERHAVEN, GERMANY.E-mail: mehler@dsm.museum

Guðmundur Ólafsson, Freyjugata 6, IS-101 REYKJAVÍK, ICELAND. E-mail: gudmuno@gmail.com

Bart Holterman, Deutsches Schifffahrtsmuseum, Leibniz-Institut für maritime Geschichte, Hans-Scharoun-Platz 1, D-27568 BREMERHAVEN, GERMANY. E-mail: holterman@dsm.museum

Joris Coolen, Zentrum für baltische und skandinavische Archäologie, Schloss Gottorf, D-24837 SCHLESWIG, GERMANY, and LWL-Archäologie für Westfalen, An den Speichern 7, D-48157 MÜNSTER, GERMANY.

E-mail: joris.coolen@lwl.org

Ragnar Edvardsson, University of Iceland, Research Center in the Westfjords, Hafnargata 9b, IS-415 BOLUNGARVÍK, ICELAND. E-mail: red@hi.is

Torbjörn Brorsson, Kontoret för Keramiska Studier, Martin Johns Väg 47, S-26375 NYHAMNSLÄGE, SWEDEN.

E-mail: torbjorn.brorsson@keramiskastudier.se

Keywords: Gautavík, trade, harbour, Bremen, Hamburg, ceramics, train oil

\section{Introduction}

Gautavík is a well-known archaeological site on the east coast of Iceland, located in a small sheltered bay on the northern side of the fjord Berufjörour (Fig. 1). It is located on a grassy plain by the sea, divided by a small river named Búðará, a place name that translates as 'river at the booths'. North of the site is a mossy slope, and to the east and south is the sea. To the west is Búðamelur, a small ridge that stretches into the sea and ends by a steep cliff by a natural deep harbour.
The two place names obviously refer to the booths at the site, with Icel. búd meaning 'booth', a 'temporary building', usually used at assembly, fishing, or trading sites. ${ }^{1}$ The site consists of four clusters of earthworks, still visible even today, which have been identified as the remains of a seasonal trading site referred to in a number of written sources from the medieval period. Although Gautavík has been a protected historical site since 1964, it was partially excavated by a team of Icelandic-German archaeologists in 1979, led by 


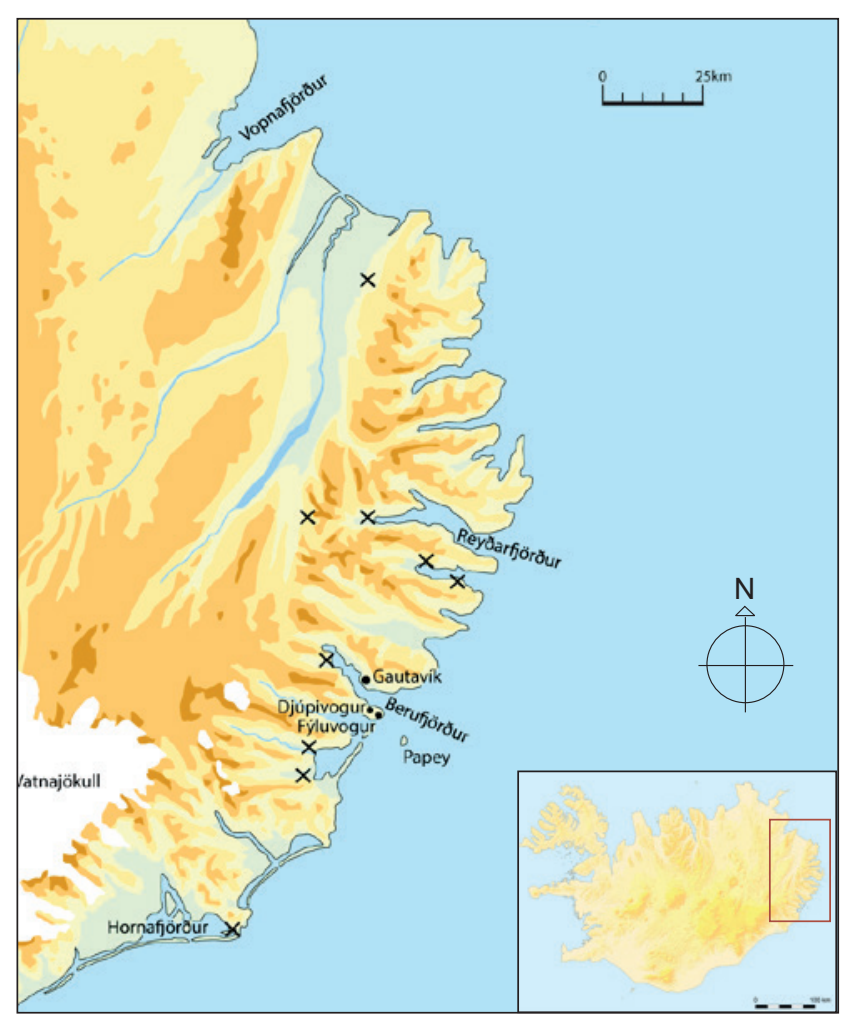

Fig. 1. Map of Eastern Iceland with sites mentioned in the text. The crosses mark locations of farms where clients of the Bremen merchants in Berufiörður lived, according to written testimonies from 1590 (illustration: Libby Mulqueeny, Mark Gardiner and Bart Holterman).

Guðmundur Ólafsson from the National Museum of Iceland and Torsten Capelle from the University of Münster, Germany. ${ }^{2}$ The aim was to explore the time period in which the site was used and the role of the place as a trading site. The remains were mapped and test excavations made in the four ruin clusters that were observed in the area (Fig. 2). ${ }^{3}$ At that time other medieval trading sites in Iceland had previously been surveyed, but very few had been archaeologically excavated. ${ }^{4}$ The first seasonal trading site that attracted the attention of archaeologists was the medieval harbour at Gásir on the north coast of Iceland, which was first investigated in $1907 .{ }^{5}$ Gautavík was the second site to be investigated, and the first where modern excavation methods were applied. In recent years, large-scale excavations have been carried out at Gásir again and at Kolkuós, both trading sites in northern Iceland, and minor investigations at Maríuhöfn on the west coast of Iceland. ${ }^{6}$ The archaeological and historical evidence related to these other sites indicates that they all were abandoned before the arrival of German merchants in Iceland in the fifteenth century.?
The current picture of Gautavík is that of a medievalperiod trading site, used in the summer only, where foreign merchants came to exchange goods with Icelanders. It is believed that during the first centuries of the settlement, Icelanders had their own ships and that oversea trade was mostly in their own hands. In the thirteenth century, the Norwegians gained control over the island's trade, and they in turn gave way in the fifteenth century to English and German merchants, with the latter dominating in the sixteenth century. The German merchants mostly desired stockfish and sulphur, but they also bought train oil and farm products, such as homespun and butter. ${ }^{8}$ When in Iceland, the merchants stayed in trading stations for which, during the second half of the sixteenth century, they had received licences from the Danish king, and they dwelled in booths built of local material. ${ }^{9}$ How Gautavík fits into this general picture of Icelandic economic history has never been assessed, mainly due to the reason that the archaeological evidence of the 1979 excavation pointed towards Gautavík ceasing to exist as a trading station around 1500, a time when German trade with Iceland was only sporadic.

Soon after the excavation of 1979 , the results were published and Gautavík became known as a seasonal trading place. ${ }^{10}$ At the turn of the millennium, the site received renewed attention, and new archaeological and historical analysis was done on Gautavík, analysis that hitherto has not been contextualized with the excavation results from 1979. In 2000, the ceramic fragments excavated in 1979 that had been dealt with only briefly in the subsequent publication were studied in more detail. ${ }^{11}$ In addition, ICP-MA/ ES analysis was done on a series of pottery fragments in 2016 in order to determine the provenance of the selected sherds. In the same year, an underwater sidescan-sonar survey was carried out in the harbour basin at Gautavík..$^{12}$ In the summer of 2015, a groundpenetrating radar (GPR) survey was conducted at the eastern part of the site. ${ }^{13}$ Furthermore, a high-resolution digital surface model and orthophotos were created, using aerial photographs taken with a kite and an unmanned aerial vehicle (UAV). ${ }^{14}$ Finally, written sources of the fifteenth and sixteenth centuries in the archives of Hamburg, Bremen and Copenhagen that relate to the German trade with Iceland were investigated..$^{15}$ There are no entries in the records of the fifteenth century about Gautavík, but records of the sixteenth century do reveal new information about the area. In what follows we present a brief overview of the excavated remains, the results of the new work 
Fig. 2. Orthophoto of Gautavik overlain on the hillshade model with the excavation trenches of 1979 marked in red and the GPR survey area in yellow. Reference grid CRS: ISN93 (graphics by Joris Coolen, after Capelle 1982, figs 10, 14, 19, 23-6, and 43; digital surface model created by Ronny Weßling/CrazyEye).

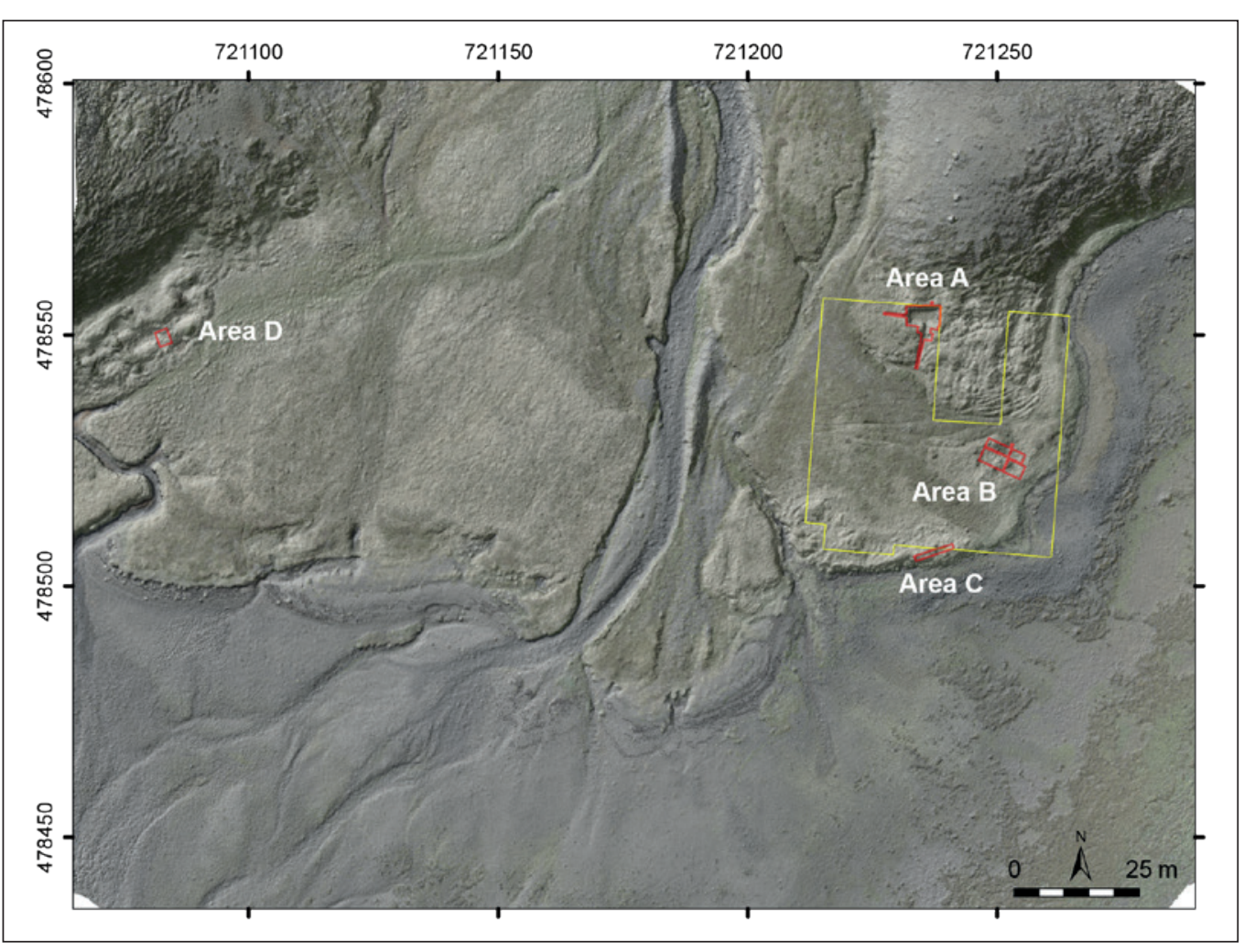

done in recent years, and a re-assessment of the site in the light of the recent archaeological and historical analysis.

\section{Results of the 1979 excavation}

In 1979, four clusters of ruins (A-D) were identified and mapped. Ruins A-C (Figs 2 and 3) were located east of the River Búðaá and ruin area $D$ is located west of the river. The site had suffered from heavy erosion by the sea and some structures had disappeared. This is the case with the area below complex C. Earthworks west of $\mathrm{C}$ indicate possible remains of booths. Remains of turf walls that were found in a small test pit below the modern-day sea level, in the eroded area south of complex D (Fig. 4), indicate the presence of earlier buildings that are no longer visible. The River Búðaá has also flooded a part of the site and perhaps destroyed or covered ruins. Ruin area A, or the East complex, turned out to be the largest building complex in Gautavík, covering almost $1000 \mathrm{~m}^{2}$. When surveyed and mapped, it was possible to distinguish between 18-20 different rooms that could be divided in four to six clusters. One of these rooms (room 1) was chosen for excavation. ${ }^{16}$ The internal dimensions were $c .6 \times 3 \mathrm{~m}$, and the walls, $c .1 .2 \mathrm{~m}$ thick and up to $0.7 \mathrm{~m}$ high, were made of turf and stone with filling of earth. Sections through the building showed two main occupational phases, which could roughly be dated by tephra (volcanic ash) layers dating to the period between the mid-fourteenth to the early sixteenth century. Tephra from 1477 was found in the younger turf walls and from the Öræfajökull eruption of 1362 in the older turf walls, providing a terminus post quem for their construction. Floor layers were up to $6 \mathrm{~cm}$ thick and many thin floor layers were found in between. While the thick floor layers point towards a longer use of the room, the thin floor layers indicate a seasonal occupation. No fireplace was found inside the building, but charcoal in the floor layers indicated the use of fire. In the thick younger floor with a terminus post quem of 1477, ceramic and brick fragments were found, as well as iron nails, a padlock, and fishing hooks made of iron. Interestingly, six to eight lead bullets were also found in the floor and the walls. Ceramic fragments and nails were also found in the older floor with the terminus post quem of 1362. Below the excavated house, older settlement remains were recorded but not excavated. They predate the tephra layer from 1362 . The excavated part in ruin area A was interpreted as the remains of a merchant's booth. The indicators for that were the excavated pottery remains (c. 60 fragments) and the lead bullets. Whether they indicate clashes between different groups of merchants at the site, as reported from other harbours, or if they originate from hunting practices cannot be determined. ${ }^{17}$ 


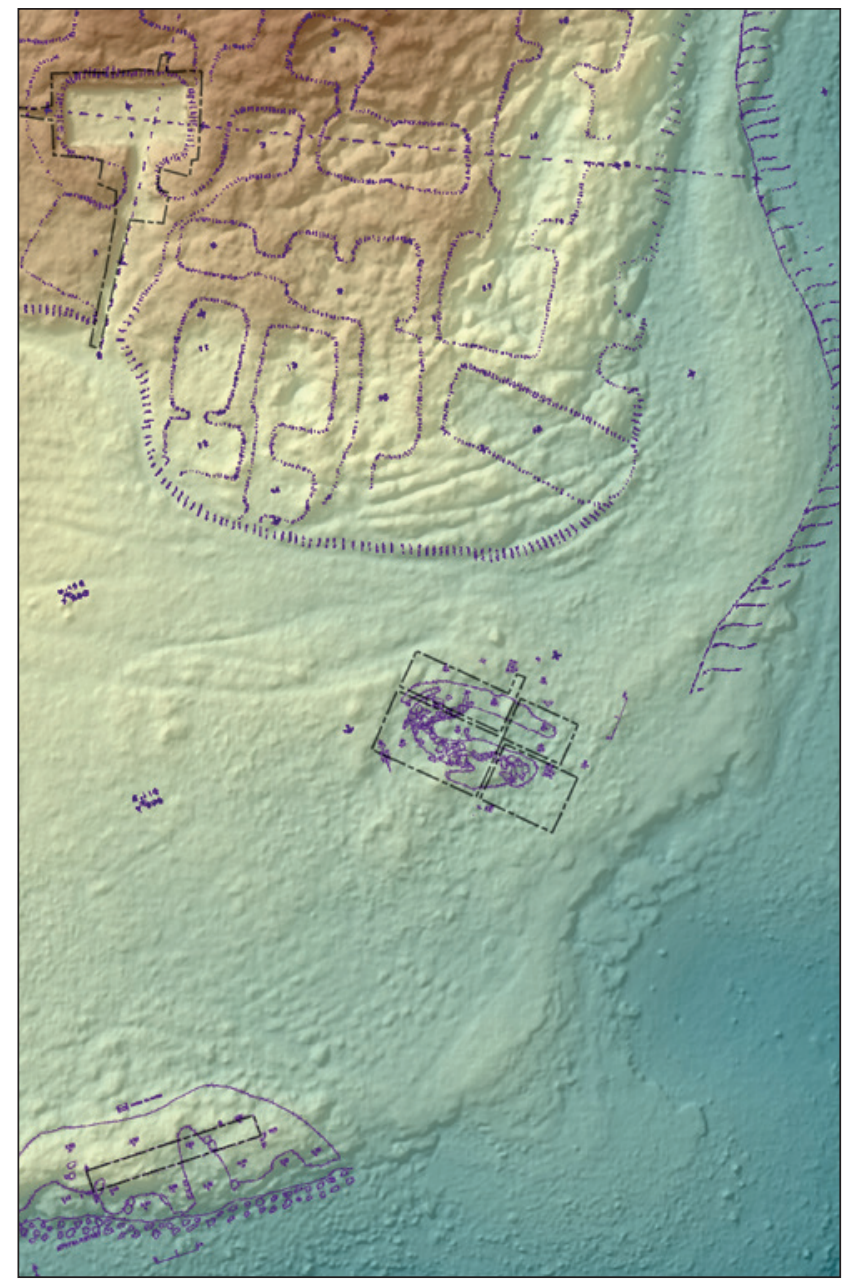

Fig. 3. Ruin areas A to $C$ as recorded in 1979 overlain on the digital surface model created in 2015. Reference grid CRS: ISN93 (graphics by Joris Coolen, after Capelle 1982, figs 10, 14, 19, 23-6; digital surface model created by Ronny Weßling/CrazyEye).

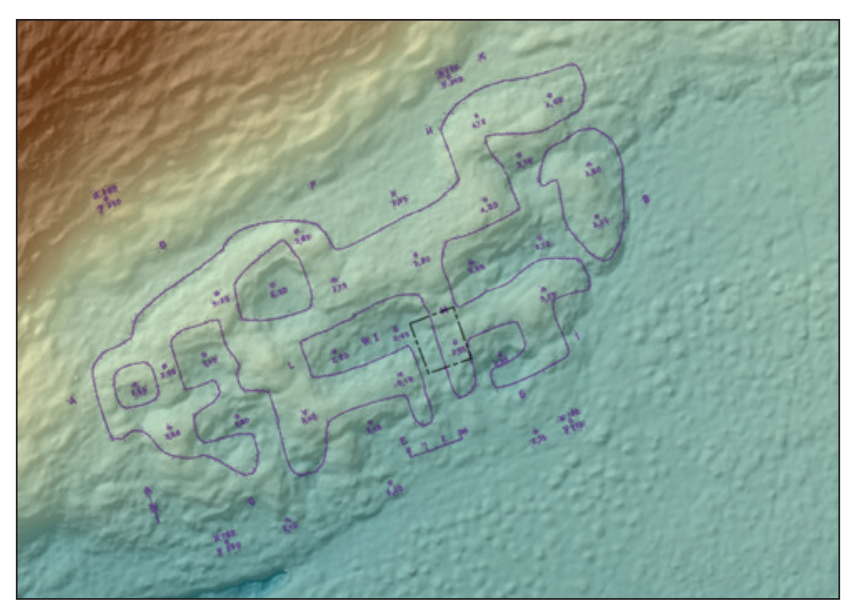

Fig. 4. Ruin area D as recorded in 1979 overlain on the digital surface model created in 2015. Reference grid CRS: ISN93 (graphics by Joris Coolen, after Capelle 1982, fig. 10, 43; digital surface model created by Ronny Weßling/CrazyEye).
Just south of ruin area A, a boathouse was excavated in ruin area $B$ (see Fig. 3). It was only c. $2 \times 5 \mathrm{~m}$ and had walls of turf and stones on three sides. The east side, facing the sea, was open and had no wall. During excavation it became clear that the boathouse had been built on top of an older building and had partly made use of older walls as a foundation for the new boathouse. By the west gable of the boathouse a unique feature was found, a circular structure of bricks with a diameter of $2.1 \mathrm{~m}$ (Fig. 5). ${ }^{18}$ The floor of this structure had been carefully laid out and the three rows of bricks of the wall that remained showed that it had been wider at the bottom than at the top, with an opening to the east. The upper part of the circular brick wall had collapsed and lay inside the structure. The number of bricks that had collapsed into the structure indicates it had consisted of at least two or three more rows of bricks. The brick structure had been laid on a large stone foundation with layers of sand in between to level it and was standing within a house built of turf and stones. ${ }^{19}$ A row of stones around three sides of the circular structure may have served as a pathway. The floor in the house, east of the circular structure, was covered by a $5 \mathrm{~cm}$ thick layer of charcoal and was $c .20 \mathrm{~cm}$ lower than the brick floor. It is important to emphasise that the charcoal layer did not extend into the brick structure. Hence, the excavators concluded that a fire was lit in front of the elevated brick structure and that hot air was led into the structure through the opening towards the east. The building was not completely excavated, and its function and form are difficult to interpret. A black volcanic ash layer from 1755 seems to have accumulated after the building had fallen out of use, but prior to its reuse as a boathouse. Another black ash layer from 1362 was found in the turf walls, while the 1477 ash layer is thought to have overlain the (charcoal) floor layer. ${ }^{20}$ This indicates that the house that surrounded the brick structure was built after 1362, but had fallen out of use before 1477.

Three interpretations for the brick structure have hitherto been put forward: Torsten Capelle suggested it is the remains of a drying kiln. ${ }^{21}$ However, such kilns are hardly known from Iceland, and none made of brick in particular, and that interpretation has never been accepted in Icelandic archaeology. Guðmundur Ólafsson suggested that the structure is the remains of a trywork to produce train oil..$^{22}$ It is noteworthy that during the excavation the remains of a 'white substance' were found in between some of the bricks and also in a small barrel hole by the south-east end of 


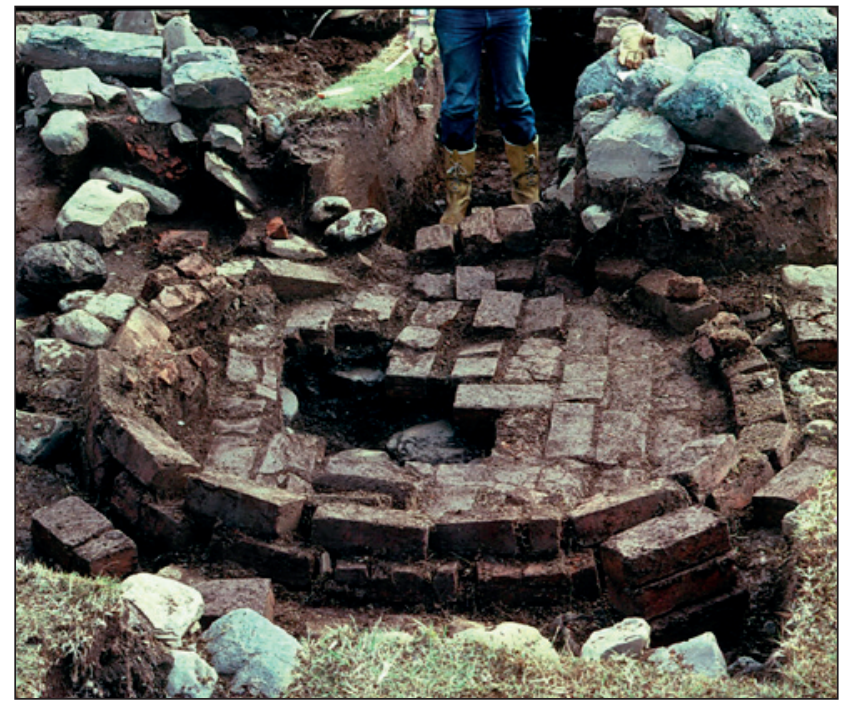

Fig. 5. Brick structure of area B during excavation in 1979 (photo: Guðmundur Ólafsson).

the building. The substance was later identified as fine white sand. ${ }^{23}$ Natascha Mehler has put forward the idea that the brick structure could also be the remains of a structure for processing sulphur. ${ }^{24}$

Building remains were also found down by the seaside (ruin area $\mathrm{C}$ ) that had almost completely eroded into the sea. Several irregular rows of stones on the beach, allegedly remains from the eroded walls, indicated that there had originally been four parallel buildings. They may have been boathouses, warehouses, or booths, and the many stray finds from that area such as ceramic fragments, nails, bricks, and animal bones indicate that this had been a busy place. ${ }^{25}$

Located by the bottom of the slope of Búðamelur ruin area $\mathrm{D}$, or the West complex, is the most visible ruin cluster at Gautavík. It attracted the attention of the Danish antiquarian Daniel Bruun, who mapped the ruins in 1901 and noted that according to oral tradition the ruins had been used by Irish merchants. This ruin complex measured $c .30 \times 17 \mathrm{~m}$ and consisted of about eight to twelve rooms, with usually two to three interconnected. ${ }^{26}$ One room, named W1, was partly excavated (c. $3 \times 2.5 \mathrm{~m})$. Volcanic ash from the Öræfajökull eruption of 1362 was found in the turf walls and showed that the house had been built later than that. Another black ash layer dating from 1477 was found above the ruin, showing that the room had most likely been in use between $c .1365$ to 1450 . No artefacts and no floor layers were found. It has been suggested that this building complex was never taken into use; if it was used, it may never have developed a proper floor layer. The ground was very wet, which made it impossible to excavate earlier cultural layers. ${ }^{27}$

\section{The ground-penetrating} radar survey

In 2015, an area of $c .2000 \mathrm{~m}^{2}$ at the eastern part of the site was investigated with ground-penetrating radar (GPR) to search for possible building remains that are not visible on the surface. It was also hoped that the GPR survey might reveal further details on the structures investigated in 1979. The survey was carried out using a Sensors \& Software pulseEkko® system with $500 \mathrm{MHz}$ antennas. Profiles were recorded in zigzag mode at $25 \mathrm{~cm}$ intervals with a $2 \mathrm{~cm}$ sampling interval and a time window of $70 \mathrm{~ns}$. The data were processed using standard filtering techniques, including a frequency filter, background removal, and Kirchhoff migration, and finally horizontal time slices (depth slices) with various intervals were created..$^{28}$

Unfortunately, due to the rough surface of the turfcovered and partly excavated ruins it was not possible to push the GPR system over the visible building remains (ruin area D and most of area $\mathrm{A}$ ). However, the survey did cover the edges of ruin area $\mathrm{A}$, as well as the remains of areas B and C (see Fig. 2). Strong reflections in the eastern part of ruin area A suggest the presence of stone walls at 1.5 to $2 \mathrm{~m}$ depth, enclosing at least one rectangular room of $c .3 .5 \times 3.3 \mathrm{~m}$ and possibly a larger room to the south (Figs 6 and 7). This does not correspond well with the plan published after the excavation, but it must be borne in mind that the latter was entirely based on the interpretation of the surface topography. We did not observe any obvious archaeological features in the GPR data in areas B and C. However, the GPR images are dominated by extensive, amorphous anomalies caused by heterogeneous natural deposits, which make it difficult to identify or interpret single anomalies. A large, V-shaped area of absorbing deposits runs diagonally across the survey area from the north-western corner towards the shoreline in the southeast. This corresponds to a dry streambed of the Búðaá River. Ruin area A lies on the edge of a bedrock outcrop, which appears as a dark area in the deeper slices and has a remarkably straight and steep edge towards the east. Area B coincides with a roughly rectangular area, which is less reflective than its surroundings. It is not clear whether this is a natural feature, connected with the Búðaá streambed, an archaeological feature, or a relic of the 1979 excavation. Although it is tempting to interpret this anomalous area as the backfill of the excavation trench, its orientation is slightly different from the excavation trench (which is still faintly visible in the 
Fig. 6. Combined depth slices of 10-50 cm (top left), 50-90 cm (top right), 90-140 cm (bottom left), and 140-190 cm (bottom right) depth. Reflecting deposits are shown dark, absorbing deposits bright (graphics by Joris Coolen; radar data: LBI ArchPro; digital terrain model: CrazyEye/Ronny Weßling).

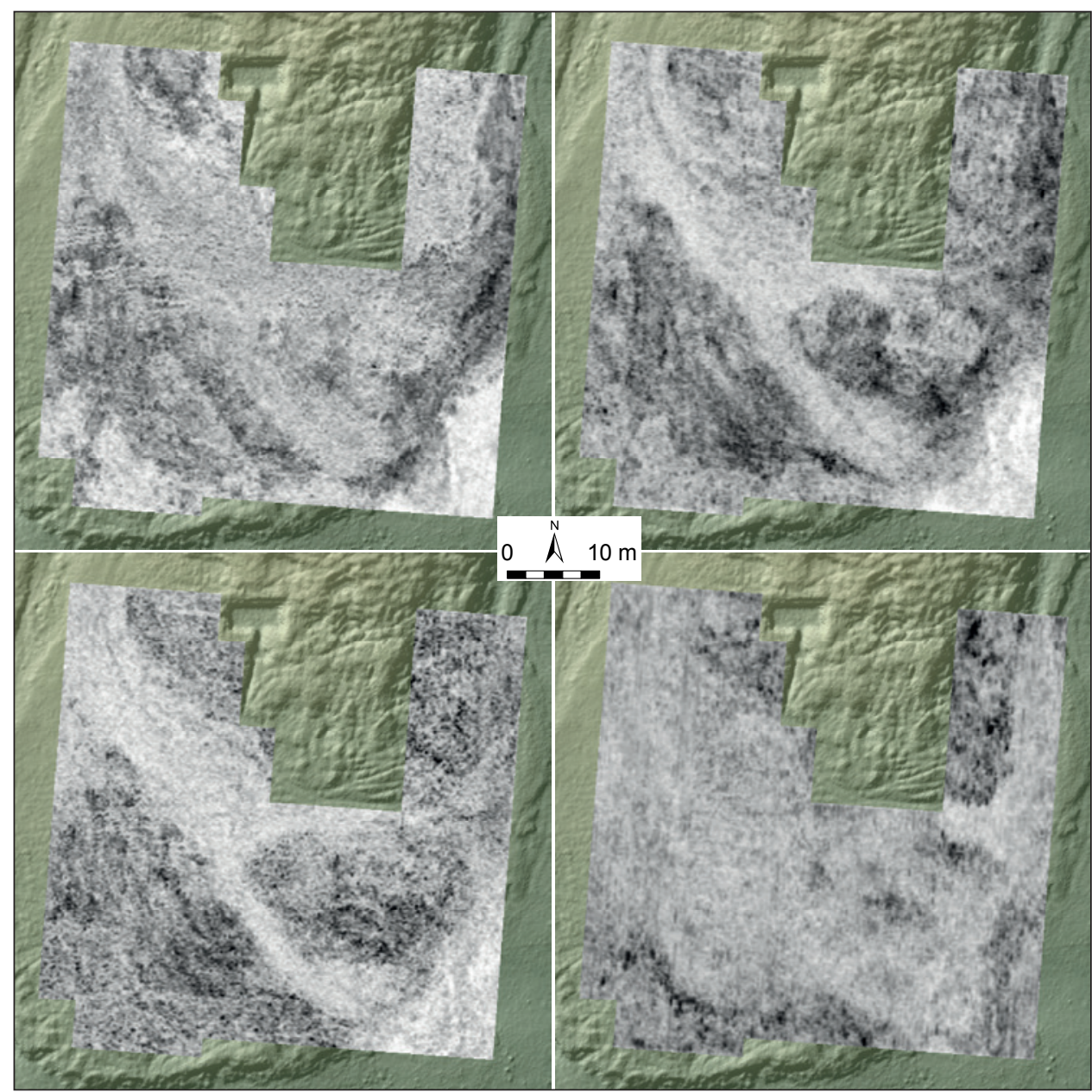

surface model). The absorbing area is most obvious at c. $50-80 \mathrm{~cm}$ depth. It is possible that the area was cleared, perhaps to provide building material for the walls of the building or boathouse.

Arguably, the most intriguing object in the GPR data is a circular feature with a diameter of approximately $4.2 \mathrm{~m}$ to the west of ruin area A, only a few meters from the excavated room 1. A linear, reflecting anomaly, possibly a drystone wall, approximately $3.5 \mathrm{~m}$ long and $70 \mathrm{~cm}$ wide, runs from the circular feature to the south. The structure appears at a depth of $c .30 \mathrm{~cm}$, but is most obvious in the time slices of c. $60-70 \mathrm{~cm}$ depth and disappears at $c .80 \mathrm{~cm}$ depth. Interestingly, the circular feature is cut by a narrow trench, which was dug across the ruin complex during the excavation in 1979 to provide a section. This section trench is visible in the GPR data, as well as in the digital surface model, and extends nearly $8 \mathrm{~m}$ beyond the western wall of room 1 . However, it seems to have been very shallow, and although the sections are mentioned in the publication, the latter does not include complete section drawings. ${ }^{29}$ It is possible that the section trench did not reach down to the feature or that the latter was simply not recognised within the narrow trench.

Since the GPR do not reveal further construction details, let alone provide any dating evidence, the newly discovered circular structure is even more difficult to interpret than the excavated brick construction

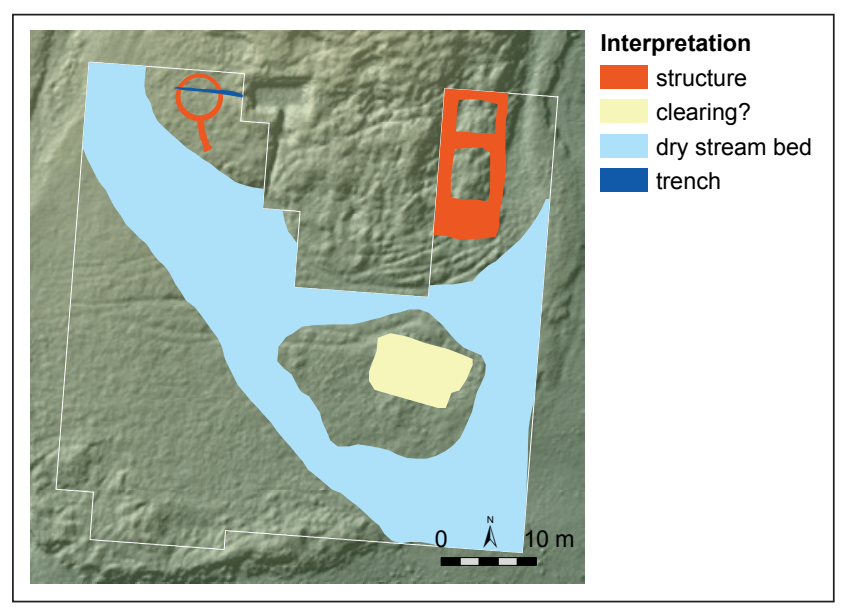

Fig. 7. Interpretation map of the GPR data, all depths (graphics by Joris Coolen; radar data: LBI ArchPro; digital terrain model: CrazyEye/Ronny Weßling). 
in area B. At present, we do not know how these two structures are temporally or functionally related. Nevertheless, that there seem to be two rather unique circular structures at Gautavík is remarkable, and we are inclined to believe that they are related.

\section{Gautavík in written records}

The place name Gautavík is not easy to explain. While vík refers to a bay, the other part does not have a clear etymology (Fig. 8). Torsten Capelle mentions that gauta refers to the Geats, the people who settled the southern Swedish area of Götaland. However, since there is no indication that people from this area ever had links with Iceland, he sees the term gauta more as a reference to foreigners who came here to trade. ${ }^{30}$

The annals and sagas that mention Gautavík are discussed in detail in the initial analysis published by Torsten Capelle and Guðmundur Ólafsson in 1982. ${ }^{31}$ All refer to events that took place between the tenth and the fourteenth century, but they are not very informative. Typically they make some brief mention, such as a ship arrived at Gautavík in this or that particular year, or a ship was equipped there for an oversea voyage, and trade took place at Gautavík. There is a reference to timber from Norway, intended for a church building in Iceland, having been landed in Gautavík in $1180 .{ }^{32}$ Ólafs saga Tryggvasonar mentions a landing bridge that was part of the trading station..$^{33}$

No written sources of the fifteenth or sixteenth century are known that mention the place name of Gautavík or a derivative thereof. However, German records of the sixteenth century in the State Archives of Hamburg and Bremen and in the Danish National Archive in Copenhagen refer to extensive trade in a region in Iceland named Ostforde, meaning 'the fjord in the East', and their contents point strongly towards a continuation of trade at Gautavík until the late sixteenth century. More specifically, a wealth of information is available for that region from the time when official licences for harbours in Iceland were introduced by the Danish king in the 1560s, after which the use of the region became heavily contested by merchants from Bremen and Hamburg.

Bremen merchants referred to a harbour at Ostforde (with many other spellings such as Ostfiord, Osteforde, Ostfiorde, Ostfiordt, Ostfohrde etc.) that they claimed to have been using since around $1500 .{ }^{34}$ The term Ostforde is poorly defined and probably originally referred to the entire eastern quarter of Iceland, not just one particular fjord or one particular harbour.
In 1567 , for example, the area was defined as ranging from Hornafjörður to Vopnafjörður and in 1582, Bremen merchants claimed that they were using the entire fjord, including the sýsla (district) in which it was located, together with Hornafjörður (see Fig. 1). ${ }^{35}$ Moreover, they were sailing to Ostforde with two ships annually, as apparently the region could not be covered with one ship alone. ${ }^{36}$ Sometimes the documents refer to Papie, a reference to the islet Papey, past which one had to sail to reach the harbour, instead of Ostforde. ${ }^{37}$ This shows that the Bremen merchants concentrated their activities in eastern Iceland in Berufjörður, at the entrance of which Papey is located.

Only in the late sixteenth century were the harbours more precisely indicated, in the wake of conflicts with Hamburg merchants. Hamburg merchants had probably been irregularly active in the area from the 1570s onwards, in close cooperation with sheriff Eiríkur Arnason in Skriðuklaustur monastery. In 1589, however, Daniel Elers from Hamburg managed to acquire a licence for the harbour Bereforde (also Bernforde, i.e. Berufjörður, as it is now called). This led to protests from merchants from Bremen, who claimed that this was the same harbour as Ostforde, for which they already had a licence. Elers countered that the fjord was called Bereforde by the Icelanders, and that a fjord named Ostforde did not exist. Two years of negotiations later, the Danish administration in Copenhagen came to the conclusion that it was impossible to decide who was right, and confirmed the use of the harbour for both parties. ${ }^{38}$

The documents about the case provide notable details for the interpretation of Gautavík. In the late sixteenth century, Hamburg merchants received licences for the harbour Bereforde with the ladested (loading station) Dupwage (Djúpivogur), whereas Bremen merchants received a licence for Ostforde in Ostfortsussel with the loading site Fuluwick (possibly the bay Fýluvogur near Djúpivogur). In a Bremen document from 1590, Fýluvogur is mentioned as the gewonliche ladelstede (ordinary loading site), which suggests that merchants were using more sites than this station in the region..$^{39}$ This is confirmed by a collection of testimonies from the customers of Bremen merchants from 1591, in which it is stated that the latter visited the former at home because the trading station was too far away. ${ }^{40}$ If we look at the places where these customers lived (see Fig. 1), it becomes clear that the extent of the trading district was still huge in the late sixteenth century, and that other trading sites besides the main ones in Djúpivogur and Fýluvogur must have been in 


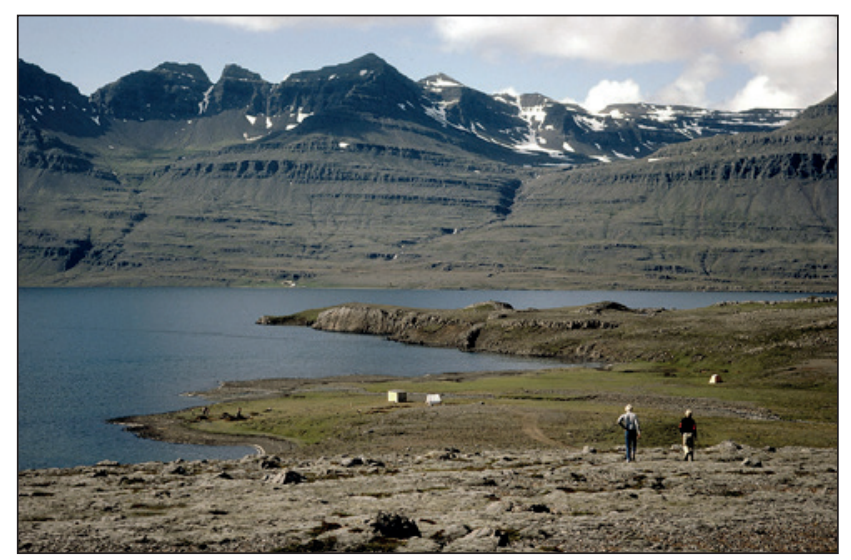

Fig. 8. Overview of Gautavik during the excavation in 1979 (photo: Guðmundur Ólafsson).

use. In other words, based on the written documents it is entirely possible that Gautavík was still in use as a German trading site in the late sixteenth century, even though the site was not explicitly named as Gautavík, as it was considered to be one of the trading sites in Ostforde. Hence, the term Ostforde may well refer to Gautavík, Fýluvogur, and Djúpivogur taken together.

\section{Underwater survey at Gautavík}

There has been a growing interest in maritime archaeology in Iceland in the past decade, with an increasing number of submerged archaeological sites being examined with archaeological methods. Underwater surveys using geophysical methods in moorings and harbours of old trading sites, whaling stations, and other types of coastal sites have revealed artefacts, structures, and even shipwrecks, dating to different periods of Icelandic history ${ }^{41}$ Icelandic written sources suggest that merchantmen and whalers primarily used natural harbours, with man-made infrastructure generally not being built until the nineteenth century. ${ }^{42}$ However, geophysical and diving surveys at the whaling station in Álftafjörður from the nineteenth century, in the north-west of Iceland, and the late medieval to early modern trading site at Básendar, on the Reykjanes peninsula, have revealed remains of smaller structures, such as wooden piers and bollards. ${ }^{43}$ The structures at the whaling station have been dated to the period between 1880 and 1900 but those detected at Básendar are as yet undated. This shows that some harbour structures are present at maritime sites in Iceland and therefore they could have existed at Gautavík. Indeed, as noted above, Óláfs saga Tryggvasonar mentions a landing bridge at Gautavík.44
The bay at Gautavík is about $500 \times 50 \mathrm{~m}$, with the trading site located at the innermost part of the bay. Two rivers run into the bay, Búðará and Gautavíkurá, and both have carried large amounts of silt into the bay. A side-scan-sonar survey was conducted in the bay in $2016 .{ }^{45}$ The north end of the bay was exposed at low tide, extending about $200 \mathrm{~m}$ to the south. This narrowed the survey area to about $300 \times 50 \mathrm{~m}$, as it was not necessary to survey the part of the bay that was visible during low tide.

The whole bay was surveyed with a side-scan sonar (Hummingbird system) from south to north. This system gives clear images of the sea floor in real time and in some cases bottom features could be interpreted in the field. The sonar works on $455 \mathrm{kHz}$ and was set to a range of $50 \mathrm{~m}$. The sonar was mounted in a tow fish, which was towed behind a boat at an average speed of $2 \mathrm{~m} / \mathrm{sec}$. The survey was carried out during high tide, when it was possible to get closer to shore.

The sonar surveys showed that the seabed was homogenous, aside from a few natural anomalies along the cliff on the west side, where a number of rocks were recorded (Fig. 9). As no anomalies suggesting man-made structures were discovered, it was decided to dive in two locations, one in the bottom of the fjord and the other at the mouth, and conduct surveys across the fjord from east to west from these two sites. The visibility during the dives was poor, about $2 \mathrm{~m}$, and the maximum dive depth was $21 \mathrm{~m}$. The dives showed that the whole seabed in the fjord was covered in deep silt, probably several meters thick. When the seabed was probed with a $1 \mathrm{~m}$ stick, the entire stick slid easily into the seabed. The dives proved, as the survey had suggested, that the seabed in the bay is homogenous, composed of mud and silt, and with little visible vegetation. On the west side, a large number of rocks were lying on the seabed, having fallen from the cliff above.

Neither the survey nor dives revealed any manmade structures on the seabed in the Gautavík bay. As mentioned above, large amounts of silt have been deposited into the bay by the two rivers that run into the bay, so that the whole northern part of the seabed is covered in silt. The depth of the bay ranges from $4 \mathrm{~m}$ in the north to $20 \mathrm{~m}$ at the mouth of the bay and the seabed is mostly composed of loose silt. It is possible that the accumulation of silt played a role in the abandonment of the site, as the bay became an unsuitable mooring for larger ships and consequently the trading site could have been moved to a better location. The silt that has accumulated in the bay may have covered 


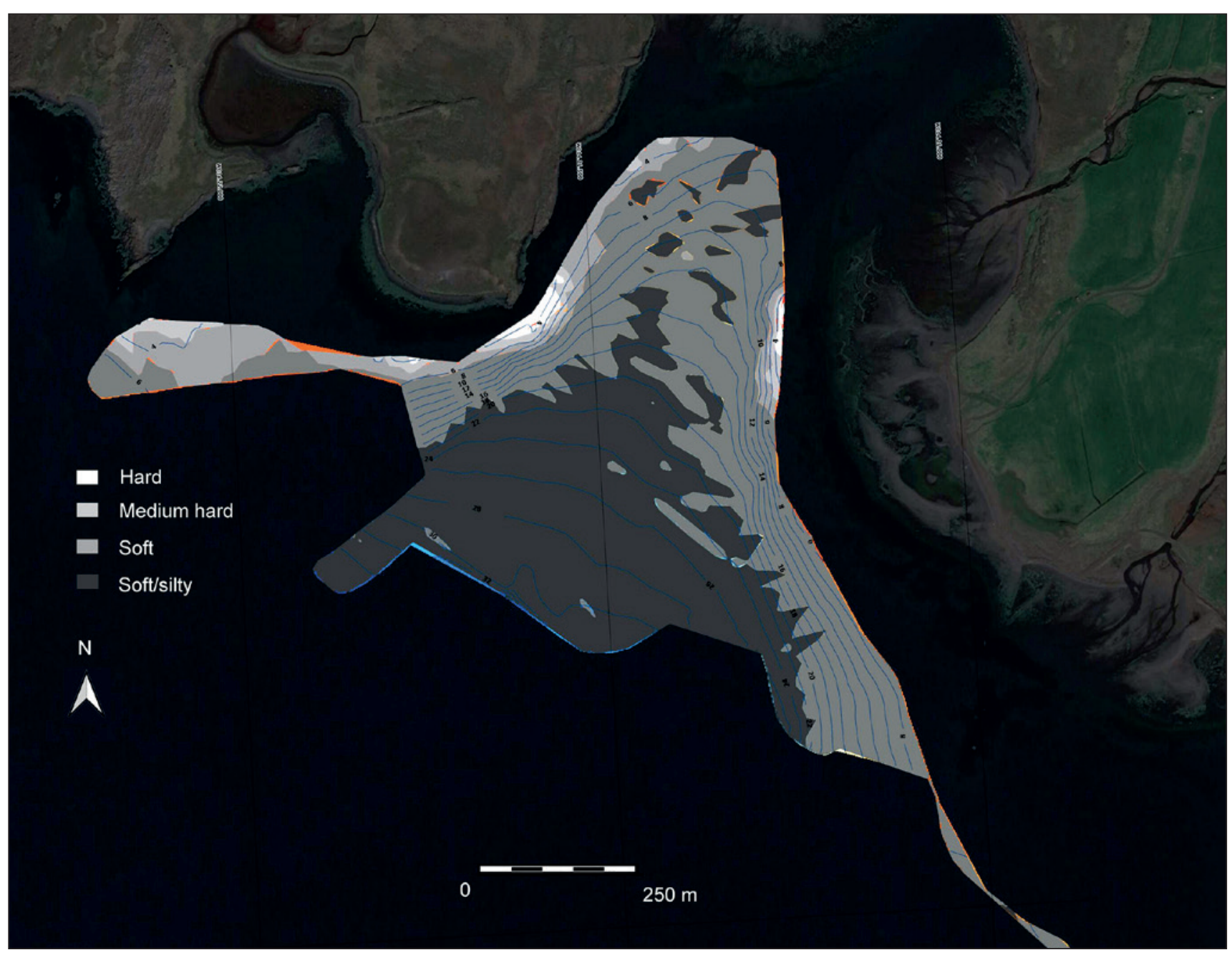

Fig. 9. The result of the underwater survey area in the harbour area of Gautavik shows the depth in meters and the composition of the seabed: dark grey indicates soft composition while light grey indicates harder surface (illustration: Ragnar Edvardsson).

any man-made structures, making them undetectable with the methods used in this survey.

\section{The ceramics excavated}

The excavations conducted at Gautavík in 1979 yielded 482 ceramic fragments, a relatively large amount for an Icelandic archaeological site of that period. A rough overview of the ceramics was presented in the publication stemming from the excavation, but neither the date nor the origin of most of the sherds could be determined at that time. ${ }^{46}$ A more thorough classification and interpretation was done in a master's thesis 20 years later, which also made an attempt to provenance the fragments. It was concluded that the pottery fragments date to the period from the fourteenth to the late sixteenth or early seventeeth century and that all have their origin in northern Continental Europe (i.e. northern Germany and possibly also the Netherlands and south Scandinavia). ${ }^{47}$ The sherds are from cooking vessels such as tripods, pots, and pans made of glazed redwares and drinking vessels, such as beakers and jugs, made of proto-stoneware and stoneware. However, the majority of fragments are hard to date and attribute to certain vessel forms, due to their high degree of fragmentation.

Since ceramics were not produced in Iceland until the nineteenth century, all ceramics had to be imported. ${ }^{48}$ Hence, ceramics contain important information about trade contacts. But while the proto-stonewares and stonewares are relatively easy to provenance, identification of the redwares is very problematic. Glazed redware cooking vessels were produced in many sites all over Northern Europe (with the exception of Norway), and very often fabrics are impossible to associate to a specific workshop or even region. The proto-stoneware and stoneware vessels excavated at Gautavík originate from potteries in Lower Saxony and the Rhineland (Germany). 
Tab. 1. Results of the ICP-MA/ES analysis of redware pottery fragments excavated at Gautavík.

\begin{tabular}{|c|c|c|c|}
\hline Find number & $\begin{array}{l}\text { Sample } \\
\text { number }\end{array}$ & Provenance & Vessel type \\
\hline & Gautavík1 & $\begin{array}{l}\text { Lübeck-Kiel } \\
\text { region }\end{array}$ & brick fragment \\
\hline & Gautavík2 & $\begin{array}{l}\text { Lübeck-Kiel } \\
\text { region }\end{array}$ & brick fragment \\
\hline GAV 1979-146-122 & Gautavík3 & $\begin{array}{l}\text { Netherlands } \\
\text { (central or north- } \\
\text { east) }\end{array}$ & tripod \\
\hline GAV 1979-146-186 & Gautavík4 & Bremen & tripod \\
\hline GAV 1979-146-256 & Gautavík5 & Bremen & tripod \\
\hline GAV 1979-146-038 & Gautavík6 & Bremen & tripod \\
\hline GAV 1979-146-002 & Gautavík7 & Bremen & tripod \\
\hline GAV 1979-146-152 & Gautavík8 & Bremen & tripod \\
\hline GAV 1979-146-166 & Gautavík9 & Bremen & tripod \\
\hline GAV 1979-146-189 & Gautavík10 & Bremen & tripod \\
\hline GAV 1979-146-157 & Gautavík11 & Bremen & handle \\
\hline GAV 1979-146-154 & Gautavík12 & Bremen area & tripod \\
\hline GAV 1979-146-192 & Gautavík13 & Bremen area & tripod \\
\hline GAV 1979-146-007 & Gautavík14 & Bremen & tripod (Fig. 10) \\
\hline GAV 1979-146-145 & Gautavík15 & Bremen & tripod \\
\hline
\end{tabular}

Another problem was the attribution of the ceramic sherds with their find contexts, or excavation areas, since the find numbers had been changed since the excavation and no record was kept of the original find spot of the sherds. Only a few fragments could be linked to the area where they were excavated. From the field diary, however, it is clear that most ceramic fragments were found in ruin area $\mathrm{A}$, the largest cluster of ruins.

In 2015, a new attempt was undertaken to provenance some of the ceramic fragments. A random selection of 13 of the excavated redware sherds associated with tripod vessels and 2 fragments of the bricks from the brick structure discovered in ruin area B were analysed using Inductively Coupled Plasma Atomic Mass Spectrometry (ICP-MA/ES) to determine their chemical composition, a standard method in ceramic analysis, and on the basis of that determine the provenance of these vessels. ${ }^{49}$ Using this method enables the determination of twelve elements that are subsequently utilized to assign the individual samples to distinct reference groups. Statistics then allows the sherds to be grouped according to chemical composition. Significant comparative material has been included in the study, including ceramics from Germany, the Netherlands, Belgium, England, Denmark, Sweden and Poland. The ICP-MA/ES analysis revealed that twelve of the thirteen sherds found at Gautavík belong to vessels manufactured in or very near Bremen. One sherd was made in the central or north-eastern Netherlands. The chemical composition of the two brick fragments places their origin in the area between Lübeck and Kiel, on the north-eastern coast of Germany. The analysed tripod vessels all date to the sixteenth or early seventeenth century (Table 1).

Thus, all but one of the vessel fragments, of which the origins could be determined, were from or near Bremen. Bremen was not only the home of many merchants who traded in the East of Iceland during that time, but also an important production site for redwares during the later medieval and early modern periods. One of the Bremen vessels found at Gautavík, a redware tripod with brown internal lead glaze (Fig. 10), is preserved to about half of its former size. Very similar pots dating to the sixteenth century have been excavated in the medieval Stephani quarter of Bremen. ${ }^{50}$ Furthermore, Bremen was a distribution hub for ceramics from nearby and regions farther away, such as the so-called Pottland, the area around Duingen in Lower Saxony (important for its many workshops that exported widely), and the Weser Uplands. ${ }^{51}$ It is worth mentioning that a fragment of a late fifteenthor early sixteenth-century ceramic horn, originating in the Weser Uplands, was found during excavations at Skriðuklaustur monastery. The monastery lies about $40 \mathrm{~km}$ north-west of Gautavík and the instrument may well have made its way to the monastery through one of the trading sites in Berufjörður. ${ }^{52}$ The Dutch vessel fragment may have come to Gautavík on board a Dutch ship, but Dutch ceramics were also exported in large numbers to cities such as Hamburg and Bremen.

It is more difficult to explain how the two brick fragments $(29 \times 16 \times 8 \mathrm{~cm}$ and $29 \times 14 \times 8 \mathrm{~cm})$ from a production site within the area of Lübeck and Kiel, Schleswig-Holstein, found their way to Gautavík..$^{33}$ Occasionally, ships from Lübeck are mentioned as having arrived in Iceland, e.g. in 1538 or in $1553 .{ }^{54}$ It may well be that one landed at Gautavík. Another possibility is that the bricks came to Gautavík on board Danish ships. The coastal area between Lübeck and Kiel was home of many brickworks that exported their products to Denmark. From the sixteenth century onwards, many bricks of that area were sold on the markets in Denmark. ${ }^{55}$ The size of the bricks excavated at Gautavík corresponds to a relatively large type that was in use from the twelfth until the seventeenth century. ${ }^{56}$ 


\section{Discussion}

The recent archaeological research carried out at Gautavík has raised considerable doubts about some of the previous interpretations of the dating and function of the site. It was mainly the re-evaluation of the ceramic material that initiated more work on the site, including an examination of the written sources in foreign archives that pertain to the German trade with Iceland. Four main questions that have emerged from the excavation and the subsequent research presented here will be discussed now.

\section{When was Gautavík abandoned?}

On the basis of the 1979 excavation and survey of the written sources available at that time, it was suggested that Gautavík was abandoned around 1500. This was corroborated by the youngest artefacts of that excavation, which were assessed at the time to 'hardly date later then the sixteenth century'. ${ }^{57}$ However, the reexamination of the ceramics has revealed that many redware fragments are of vessels that were produced in the sixteenth century, with some vessel types even ranging into the early seventeenth century. The longevity of many of these vessel types, the production range of which spanned the sixteenth and early seventeenth centuries, makes it impossible to determine a precise date for the abandonment of Gautavík on the basis of the ceramics alone. Additional proof of the site being used throughout the sixteenth century comes from the Iceland map made by Antwerp cartographer Abraham Ortelius (1527-1598) in 1585 and published in 1590 (Fig. 11). Gautavík, marked on this map as Garavig in Bernfiord, is the only settlement or harbour in the area between Vopnafjörður and Hornafjörður. It has been assumed that bishop Guðbrandur Porláksson (1541-1627) helped Ortelius produce his map of Iceland with his knowledge of the local topograhy. ${ }^{58}$ As already pointed out by Guðmundur Ólafsson and Torsten Capelle, the site is not mentioned on later maps. ${ }^{59}$ Furthermore, written evidence from German and Danish archives indicates that Gautavík may have been visited through the last years of the sixteenth century.

On the basis of the ceramics excavated, the written evidence, and the Ortelius map, then, we suggest that overseas trading activities at Gautavík ceased to exist shortly before 1600 and that its trade was shifted to Fýluvogur and Djúpivogur, the harbours that were established in the 1570s. They are first mentioned as main trading sites of the Germans in 1590-but they

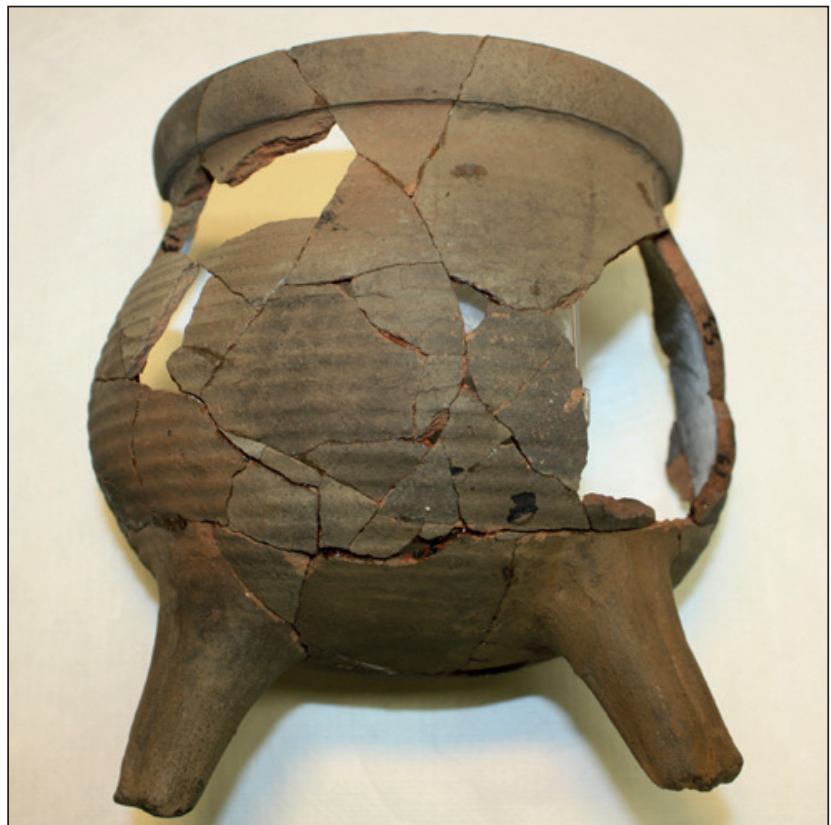

Fig. 10. Redware tripod pot (find nr. GAV 1979146-007) excavated at Gautavík and originating in Bremen (photo: Natascha Mehler).

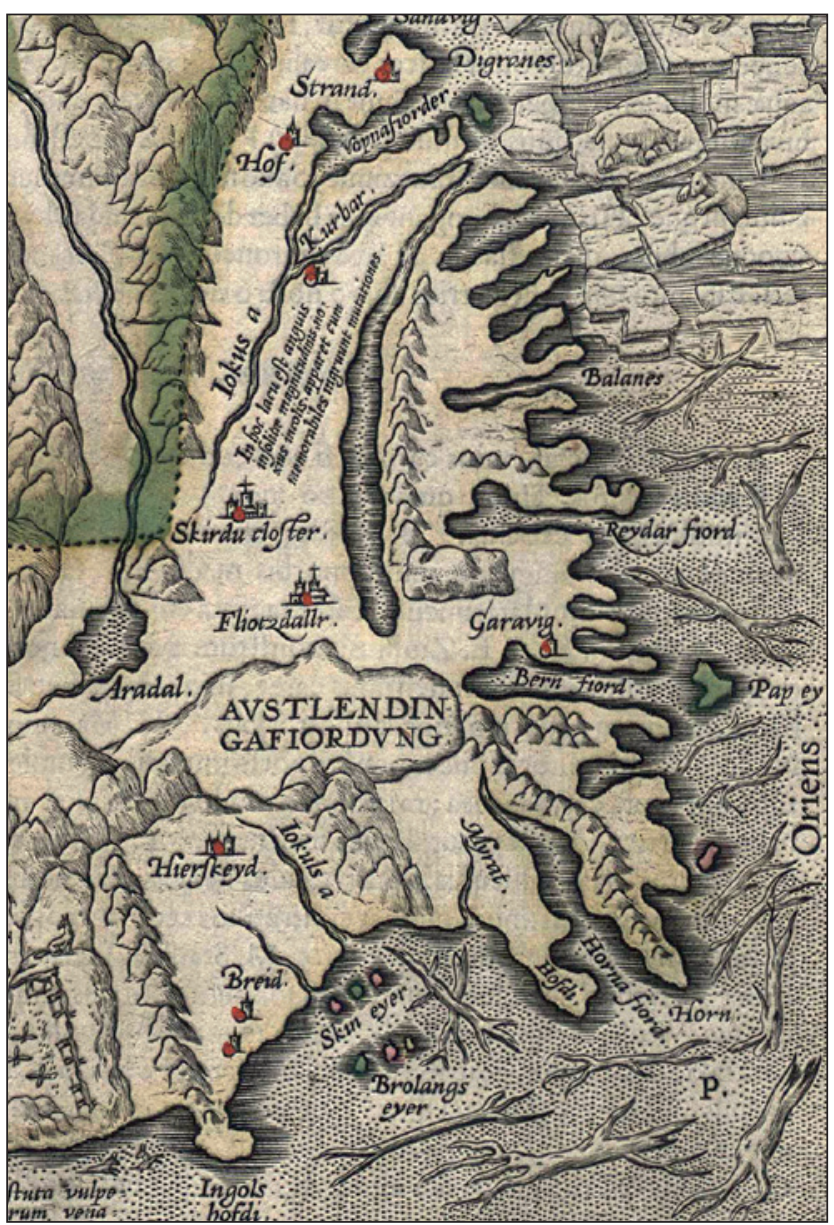

Fig. 11. The eastern coast of Iceland from the Abraham Ortelius map of Iceland, published 1590 (map from Íslandskort, Háskólabókasafn). 
must have existed earlier then that. In the late sixteenth century Fýluvogur and Djúpivogur eventually took away the bulk of the trade in the area, with Gautavík maybe being used for a couple of years until it finally fell out of use. Why Gautavík fell out of use is hard to tell. Maybe the accumulation of silt transported from the rivers into the harbour basin played a role in the abandonment of the site, with the bay having become an unsuitable mooring for larger ships, as the results of the underwater survey suggest.

\section{Trading site or farm, or both?}

Despite some examples having been partially excavated in Iceland, medieval coastal trading sites are not well understood. The general picture that was developed based on past examinations of sites such as Gásir or Kolkuós was that such sites were used only during the summer months and consisted of relatively simple booth structures used as dwellings or for storage of goods and equipment. However, upon a closer look Gautavík differs from the other coastal trading sites for two main reasons, the brick structure and the layout of the buildings, which raises the question of the site's function. May Gautavík have been a farm with a harbour function?

Fljótsdæla saga, written down probably in the fifteenth century, mentions a ship arriving at Gautavík and the crew staying there over the winter. ${ }^{60}$ If this holds true, it is hard to imagine that the crew remained there in simple booths; it is more likely that they would have dwelled in farm buildings. Indeed, Víglundar saga, dating to the end of the fourteenth or beginning of the fifteenth century, mentions that a farmer from Gautavík met a ship that had reached the harbour. It is noteworthy that the Icelandic wording used here is Gautavík $i$ Austfördum, i.e. in the Eastern Fjord, which literally translates as the German Ostfjord. We know that there was still a farm at Gautavík in the early seventeenth century, when Ottoman pirates on slave raids marauded in Berufjörður in 1627. Records tell of pirates plundering Djúpivogur and also trying to set fire to the farm of Gautavík, from which nine people were abducted. ${ }^{61}$ Maybe the lead bullets excavated in ruin area A relate to that event ${ }^{62}$ Today, the modern farm of Gautavík is located $600 \mathrm{~m}$ east of the site, at a distance of $250 \mathrm{~m}$ from the sea.

The layout of the buildings at Gautavík and their clustering differs from that at other coastal trading sites. The ruins in area $C$ could be the remains of boathouses, a building type which has not yet been recorded at Gásir (although such structures might have existed and have now been eroded). The existence of boathouses would suggest year-round use of the site, where boats were secured in boathouses over the winter. Indeed, the ruin clusters of area D differ from the irregular assemblages of small booth structures of coastal trading sites like Gásir. Furthermore, the rectangular room excavated in area A, built during the mid-fourteenth century and modified later, was built of stone and turf walls, with at least three rows of stones surviving. ${ }^{63}$ Such solid construction has not been observed at booths at any other coastal trading site. All of the ruin areas seem to have a long and complex history and more excavations are needed to understand the site fully.

The written and archaeological evidence now suggests that Gautavík was in use for at least 400 years. The oldest written mention of Gautavík goes back to the late twelfth century, and the site gradually fell out of use in the last years of the sixteenth century, as we suggest here.$^{64}$ It may have been a seasonal trading site at some point in time, but given the regional importance of the place for quite some time, the layout of the ruin clusters, and the evidence for a farm from written sources it is hard to imagine that nobody was living there permanently, at least periodically.

\section{Was train oil produced at Gautavík?}

As mentioned above, three interpretations have been put forward for the round brick structure excavated in area B: a drying kiln, a train oil trywork, or a sulphurprocessing structure. The train oil trywork has been the one most favoured by archaeologists working with Icelandic material. This interpretation is primarily based on comparative material excavated at the seventeenth-century Dutch whaling station at Strákatangi on the western coast of Iceland, which revealed a similar brick construction, and on contemporary illustrations of the construction of Dutch tryworks. ${ }^{65}$ In these, a round brick construction supports an iron cauldron in which whale fat is melted.

Icelanders needed train oil for many purposes, but mostly for lighting their homes and processing sulphur. Sulphur was collected at sites in the southwest and north of Iceland and then refined by adding train oil while the sulphur melted in iron pans. Large quantities of train oil were needed for this, as the sulphur export trade was considerable, and in 1562 the Danish king introduced both a sulphur and train oil monopoly and forbade all export by German merchants, unless they had bought the former from his middle men. ${ }^{66}$ Train oil was also a sought-after commodity in northern Germany. A late sixteenth-century description 
of Iceland, written by the German traveler Dithmar Blefken, reports that Germans brought train oil from Iceland to the Hanseatic cities because tanners and shoemakers were in great need of it. ${ }^{67}$

Here some brief explanation is in order of what train oil was made of. Most of the documents that mention the export of thran to Hamburg or Bremen do not specify whether this was extracted from whale or other sea mammals or fish, such as cod, but occasionally train oil production from seal fat is mentioned. ${ }^{68}$ According to Icelandic sources, seal fat was a very important source of the raw material for train oil, as were livers from Greenland sharks (Somniosus microcephalus) ${ }^{69}$ There was no commercial whaling in the fifteenth and sixteenth centuries; whale blubber at that time was only available when animals stranded themselves.

So, was train oil produced at Gautavík for German (or other) merchants? With the written sources on the German trade with Iceland now having been investigated, we can add that in 1591 the Hamburg merchant Joachim Warneke bought train oil (thran) and fish in 'all places in the bays belonging to Bernforde'. ${ }^{70}$ Whether this was purchased in Gautavík or Fýluvogur or Djúpivogur the document does not reveal, but it shows that train oil was produced at several sites in Berufjörður at that time. The GPR survey of 2015 revealed the traces of another round structure that appears to be quite similar to the one excavated in 1979, only larger in dimension. It is tempting to interpret this newly discovered structure as another construction for the processing of train oil, but further excavation is needed to confirm this conjecture. If these structures testify to train oil production at Gautavík prior to $c$. 1600, the site would indeed be of considerable importance for foreign traders.

Last, but not least, we would like to propose a fourth interpretation for the round structure excavated in 1979. The round brick wall tapering upwards could indicate that the structure once consisted of a cupola. ${ }^{71}$ Such a construction bears a striking resemblance to medieval baking ovens excavated in northern Germany. Throughout the Middle Ages and early modern period, most baking ovens consisted of a single chamber with a single opening. ${ }^{72}$ The oven was heated up by lighting a fire inside the oven, with smoke escaping through the opening in the front. When the oven was hot enough, the embers were brushed out and the bread or other food was put inside. Many examples of such ovens made of brick and with similar diameters are known, e.g. from Lübeck, which were primarily used to bake bread. ${ }^{73}$ However, the brick floor of the round structure excavated in Gautavík did not show obvious traces of fire; charcoal was found outside the structure.

The interpretation of the structure as a baking oven seems rather implausible in an Icelandic context. Icelanders did not bake their bread with the help of baking ovens but made flat bread over an open fire instead. Bread was not eaten too often, since cereals did not grow in Iceland in that period and all cereals or flour had to be imported. ${ }^{74}$ However, German merchants and sailors may well have wanted bread, since according to written sources the Icelandic diet did not appeal to them. Hamburg merchants who traded in Hrútafjörður in the north-west of Iceland, for example, complain that the crews had to eat 'unnatural food' because his people could not get bread. ${ }^{75}$ This might have been reason enough for some of the Germans to build a baking oven at Gautavík, a site they used regularly, with bricks they had brought, in oder to make bread out of flour they had also brought.

\section{Who visited the harbour of Gautavík?}

The earliest written records concerning Gautavík from the late twelfth to the fourteenth century that refer to the harbour there stem from a period in which Iceland had strong trading links with Norway, and indeed some of the early references tell of ship traffic between Gautavík and Norway. ${ }^{76}$ During that time a landing bridge seems to have existed at the harbour. At some time in the early fifteenth century the English started to visit Iceland in ever greater numbers. ${ }^{77}$ Given the importance of Gautavík, they may well have visited the harbour, but we have no evidence for this as yet. No written sources mention an English visit to Gautavík. No English ceramics were found during the work at Gautavík, but English ceramics are generally very rare in Iceland and only a small part of Gautavík was excavated. ${ }^{78}$ From around 1500 until c. 1620, when the Danish trade monopoly was firmly established, we can trace Bremen merchants in Ostforde, with Hamburg merchants coming in as well around 1570 at the latest. The redware cooking vessels that originated in or near Bremen found at Gautavík confirm this.

All in all, the evidence points towards Gautavík being a trading site that could have been a settlement inhabited year-round, if only periodically. Foreign merchant vessels visited the harbour throughout the existence of the place. It may well be that train oil was produced here. Gautavík was a settlement of regional importance, being the main port of entry in Berufjörour and the wider area at least from the twelfth century until 
the last years of the sixteenth, when trade was gradually relocated to the mouth of the fjord. Djúpivogur was established here as a trading site in the 1570s and from $c .1590$ at the latest was in the hands of Hamburg merchants, with Bremen merchants having their trading post nearby at Fýluvogur. In the early seventeenth century, with the establishment of the Danish trade monopoly, the Germans retreated from Berufjörður.

\section{Acknowledgements}

The excavation of 1979 was led by Guðmundur Ólafsson and Torsten Capelle. Sadly, Torsten Capelle passed away in 2014; we would have liked to discuss our views on Gautavík with him, but we were able to do so with Birgit Mecke (LWL-Archäologie für Westfalen), who was one of the students excavating at Gautavík at that time. The marine and terrestrial geophysical survey work of 2015 was conducted as part of the project Harbours in the North Atlantic (c. 800-1300), funded by the German Research Council (DFG, grant no. CA 146/17-1). The ICP-MA/ ES analysis and the analysis of the written sources was part of the project Between the North Sea and Norwegian Sea- Interdisciplinary studies of the Hanseatic League, funded by the Leibniz Association (grant no. P81/2014). Both projects were led by Natascha Mehler. The written sources referred to in this paper are accessible online in HansDoc, the database of primary sources pertaining to the trade of North German towns with the North Atlantic. ${ }^{79}$

We would like to thank Mark Gardiner, Lincoln University, for his indispensable help in the field during all weather conditions and for helping us think through the history of the place. The GPR survey was carried out by Hannes Schiel and Jakob Kainz on behalf of the Ludwig Boltzmann Institute for Archaeological Prospection and Virtual Archaeology, Vienna. We are also grateful to Alois Eder-Hinterleiter (Zentralanstalt für Meteorologie und Geodynamik, Vienna) for additional data processing. The digital terrain model of Gautavík was created by Ronny Weßling, CrazyEye Perspective, Vienna. John Preston, Edinburgh University, and Marianne Nitter, Stavanger University, helped us during our site visit in 2015. Thanks also to Dieter Bischop, Landesarchäologie Bremen, Aleike van de Venne, and Frauke Witte, Museum Sønderjylland, for their help with reassessing the pottery, and to Daniel McNaughton, who looked after our English.

\section{Endnotes}

${ }^{1}$ On booth structures at Icelandic assembly sites, see Vésteinsson 2013.

${ }^{2}$ Georgsson 1990, 59.

3 Capelle 1982.

${ }^{4}$ Gardiner and Mehler 2007, 389-393.

${ }^{5}$ Jónsson 1908, 3-8; Bruun 1928, 125-126;

${ }^{6}$ On Gásir see Roberts 2002; Roberts 2003; Roberts 2005; on Kolkúos see Traustadóttir and Bolender 2002; Traustadóttir and Svenson 2011; Traustadóttir and Svenson 2012; on Maríuhöfn see Porkelsson 2004.

7 An overview on the German trade with Iceland is given in the introductory chapter by Gardiner and Mehler, this volume.

8 Porsteinsson and Grímsdóttir 1989, 160-171; Porsteinsson and Grímsdóttir 1990, 118-123; Porsteinsson and Jónsson 1991, 165; Hofmeister 2000.

${ }^{9}$ Gardiner and Mehler 2007.

${ }^{10}$ Capelle 1982.

${ }^{11}$ Mehler 2000, 67-73; Mehler 2004.

${ }^{12}$ Edvardsson 2018.

${ }^{13}$ The GPR survey was carried out by the Ludwig Boltzmann Institute for Archaeological Prospection and Virtual Archaeology (LBI ArchPro) from Vienna, Austria, in cooperation with the Centre for Baltic and Scandinavian Archaeology (ZBSA) in Schleswig, Germany, and was part of the DFG-funded research project 'Harbours in the North Atlantic AD 800-1300' (HaNoA), directed by Natascha Mehler.

${ }^{14}$ The surface model and orthophotos were created by Ronny Weßling (CrazyEye Perspective) for the HaNoA project in 2015, following on an initial survey using kite aerial photography in 2012.

${ }^{15}$ Holterman 2018a.

${ }^{16}$ Ólafsson 1980, 24-26; Ólafsson 1982, 60-68; Ólafsson 2005, 8-14.

${ }^{17}$ Porsteinsson and Grímsdóttir 1990, 118-122.

${ }^{18}$ Capelle 1982, 39-60; Ólafsson 2005, 15-17.

${ }^{19}$ Capelle 1982, 43-44.

${ }^{20}$ Ibid., $53 f$.

${ }^{21}$ Ibid., 56-59.

${ }^{22}$ Ólafsson 2005, 15-16.

${ }^{23}$ Capelle 1982, 51-52 and footnote 102: A sample was analysed at the Department of Geography at the University at Münster, revealing that it is silty fine sand (German 'schluffiger Feinsand') differing only in terms of colour from the other contexts. In a personal communication in 2011 Torsten Capelle reported that nothing remains of that sample.

${ }^{24}$ Mehler 2007, 239; on sulphur processing, see Mehler 2015,208 . This interpretation of the Gautavík brick structure as a sulphur - processing structure is primarily based on a depiction of round built structures on the map of Iceland published in 1539 as part of the Carta Marina, the well-known map of Swedish bishop Olaus Magnus. The structures are next to a barrel labelled 'SVLFVR'. However, no sulphur was found during the excavation.

${ }^{25}$ Capelle 1982, 33-38.

${ }^{26}$ Bruun 1928, 125-126.

${ }^{27}$ Capelle 1982, 30-32. 
${ }^{28}$ The depth indications are based on a velocity model with a linear decrease from $0.09 \mathrm{~m} / \mathrm{ns}$ at the surface to $0.07 \mathrm{~m} / \mathrm{ns}$ at $30 \mathrm{~ns}$ two-way traveltime and beyond. As the exact velocity is not known and may vary throughout the survey area, the depths provided in this section are only an estimation. As the GPR data have not been topographically corrected, the depth slices should not be considered plane, but are parallel to the present surface.

${ }^{29}$ Capelle 1982, 61.

${ }^{30}$ Ibid., 26.

${ }^{31}$ Ibid., 26-29.

${ }^{32}$ Gautavík is mentioned in Hrafns saga Sveinbjarnarsonar 1967, 9; Íslendinga sögur og prettir III 1987, 1975, 1981, 2305, 2310; Íslendinga sögur og pattir I 1987, 700; Njáls saga 1954, 20, 56, 208.

${ }^{33}$ Capelle 1982, $27 f$.

${ }^{34}$ For example, in a letter from 28 February 1567 (RAK D11, Pakke 25 (Suppl. II, 15)), they claimed to have been visiting the harbour for around seventy years.

${ }^{35}$ StAB 2-R.11.ff.: instruction for Tyleman Zerneman, 26 September 1567.

${ }^{36}$ RAK D11, Pakke 25 (Suppl. II, 15): complaint against Hamburg merchants, 18 January 1580: 'wir die have Oistfortt sambt dessenn sussell, unnd dabey gelegene Hornefortt, eine vast geraume unnd lange zeitt von jharenn hero, anfenglich mit einem, hernacher aber alle wege mit zweyen unsern schiffenn [...] besiegeldt'.

${ }^{37}$ StAB 2-R.11.ff.: instruction for Daniel Bisterfeldt, 14 November 1591: 'diese havinge Oistfiortt auch Papie genandt wirde nun sey aber Papie einn eilandt so bey der Oistfiortt so nahentt liege, das mann dabey hinein ann die have siegelenn mu., unnd dahero umb mehrer gewißheitt willen dieser havinge dieselbige von solchem eilande auch Papie genantt wordenn'.

${ }^{38}$ Holterman 2018a, 279-280.

${ }^{39}$ StAB, 2-R.11.ff.: instruction for secretary Daniel Bisterfeldt, 14 October 1590.

${ }^{40}$ For example in the testimony of the priest Einar Magnússon (RAK D11, Pakke 26 (Suppl. II, no. 16): 'item mit ihren schuten furenn sie den leuten zu hauß ihre notrufft auf ihre eigene unkostunge unnd suchenn selbst wieder waß die landeßleute thuen konnen in bezalunge anthuen, [...] dann eß sein hir bose wege das das folck ihre notrufft selbest nicht konnen suchenn wieder mit pferden oder böetenn'.

${ }^{41}$ Edvardsson and Egilsson 2011.

${ }^{42}$ Olavius 1964; Pór 2002; Ann. Isl. 1.3., 1924; Ann. Isl. 1.4., 1924.

${ }^{43}$ On German traders at Básendar, see Holterman 2018b.

${ }^{44}$ Capelle 1982, $27 \mathrm{f}$

${ }^{45}$ Edvardsson 2018.

${ }^{46}$ Capelle 1982, 69-78.

${ }^{47}$ Mehler 2000, 67-73.

${ }^{48}$ Sveinbjarnardóttir 1996.

${ }^{49} \mathrm{On}$ ICP-MA/ES analysis as a method in ceramic research, see Thompson and Walsh 1989.

${ }^{50}$ Bischop 2014.

${ }^{51}$ Rech 2004, 337-339.

${ }^{52}$ Mehler et al. 2018.

${ }^{53}$ Thorsten Capelle did suggest that the bricks originated in the Lübeck area (Capelle 1982, 43).
${ }^{54}$ Bei der Wieden 1994, 15, 17.

${ }^{55}$ Bertelsen 2010.

${ }^{56}$ The brick size of $c .29 \mathrm{~cm}$ in length corresponds to the medieval brick length, ranging between 28 and $31 \mathrm{~cm}$, and is generally known as 'Klosterformat'; see Möller 2008, 13.

${ }^{57}$ Capelle 1982, 87.

${ }^{58}$ Sigurðsson 1978, 9-68; https://islandskort.is/en/map/ show/2 (last accessed June 2019).

${ }^{59}$ Capelle 1982, 87.

${ }^{60}$ Ibid., 28.

${ }^{61}$ Helgason 2018, 73, 78.

${ }^{62}$ The lead bullets are about $10-12 \mathrm{~mm}$ in diameter; see Capelle 1982, 83.

${ }^{63}$ Ibid., 68.

${ }^{64}$ Ibid., 26.

${ }^{65}$ Paulsen et al. 2008; Edvardsson and Rafnsson 2011. For contemporary illustrations of Dutch tryworks, see Ólafsson 2005, 16.

${ }^{66}$ Mehler 2015, 199, 202.

${ }^{67}$ Holterman 2018a, 39.

${ }^{68}$ The Middle Low German word tran, or thran in the documents seems to refer mostly to train oil made from fish; see Köbler 2014, sub verbum tran. Online at https://www.koeblergerhard.de/mndwbhin.html (last accessed June 2019). A document from 1476 mentions the German skipper Johannis Rorembergh having been robbed in Iceland by the English, who also took from him 'quatuor tonnas focinae pinguedinis in unguentem resolutae, quae penes nos vulgariter lyse dicitur' (four barrels of seal fat dissolved in a solution which is commonly called lyse). RAK Bartholins safn E, 108-112; also published here: https://hansdoc.dsm.museum/ Docs/14760307BER00.html (last accessed June 2019).

${ }^{69}$ Kristjánsson 1983, 319-322, 370-373.

${ }^{70}$ RAK D11, Pakke 26 (Suppl. II, no. 16). 'auff allen örten der Bernfiorthen zugehorigen einwiecken'; https:// hansdoc.dsm.museum/Docs/15911220KOB00.html

${ }^{71}$ Capelle 1982, 44.

${ }^{72}$ Suchowa 2002, 50; van de Venne 2008; Grabowski 2007, 135 and fig. 6.

${ }^{73}$ For example, see Grabowski 2007, fig. 6

${ }^{74} \mathrm{On}$ the cultivation of barley in Iceland, see Trigg et al. 2009.

75 ' und wegen biehr und brodts mangell, haben mußen wasser trinckenn, und unnattuerliche speiße essenn'; StAHH, 111-1 (Senat), Cl. VII Lit. Kc No. 11, vol. 4 (Islandia Saec. XVII); see also https://hansdoc.dsm. museum/Docs/16030408HAM00.html; it is also worth mentioning that the Hamburg merchant Gories Peerse, in his account of Iceland, published in 1561, writes 'Without salt and bread, they think food is good. They greedily eat fatty seal blubber, without salt and bread in their bowl'; see the online translation at http:// www.facultysite.sinanewt.on-rev.com/yslandt.pdf (last accessed June 2019).

${ }^{76}$ Capelle 1982, 26-29.

${ }^{77}$ See introductory chapter by Gardiner and Mehler, this volume.

${ }^{78}$ On English ceramics found in Iceland, see Mehler 2000, 38-41.

${ }^{79}$ https://hansdoc.dsm.museum (last accessed June 2019). 


\section{References}

\section{Unpublished documentary sources}

(see also list of abbreviations)

RAK - Rigsarkivet, København

Printed sources (see also list of abbreviations)

Ann. Isl. - Annales Islandici Posteriorum Saeculorum, vol. 1.3. ('Seiluannáll.') and vol. 1.4. ('Vallaannáll.'). Reykjavík: Hið íslenska bókmenntafélag, 1924.

Hrafns saga Sveinbjarnarsonar, ed. by A. Hasle. Editiones Arnamagnæanæ. Series B, 25. Copenhagen 1967.

Íslendinga sögur og paettir III, ed. by B. Halldórsson, J. Torfason, S. Tómasson and Ö. Thorsson. Reykjavík: Svart á hvítu, 1987.

Njáls saga, Íslenzk fornrit VII, ed. by E. Ó. Sveinsson. Reykjavík: Hið íslenska fornritafélag, 1954.

\section{Secondary literature}

Bei der Wieden, H. 1994. Lübeckische Islandfahrt vom 15. bis 17. Jahrhundert. Zeitschrift des Vereins für Lübeckische Geschichte und Altertumskunde 74, 9-30.

Bertelsen, T. 2010. Teglstensformater og forbandter i danmarks middelalder og renæssance, in K. H. Clausen and T. A. Vestergaard (eds), Flensborgsten - om murstensformater, teglhandel og arkitektur, 58-65. Haderslev: Museum Sønderjylland.

Bischop, D. 2014. Die Ausgrabungen im Bremer Stephaniviertel beim Neubau von Radio Bremen 2004 bis 2005, in A. Falk, U. Müller and M. Schneider (eds), Lübeck und der Hanseraum. Festschrift für Manfred Gläser, 245-255. Lübeck: Schmidt-Römhild.

Bruun, D. 1928. Fortidsminder og nutidshjem paa Island. Copenhagen: Gyldendalske boghandel.

Capelle, T. 1982. Untersuchungen auf dem mittelalterlichen Handelsplatz Gautavík, Island. Köln: Rheinland-Verlag.

Edvardsson, R. 2018. Underwater survey at the medieval trading site in Gautavik. Preliminary Report. Bolungarvík: Rannsóknasetur Háskóla Îslands á Vestfjörðum.

Edvardsson, R. and Egilsson, A. P. 2011. Archaeological assessement of selected submerged sites in Vestfirðir. Archaeologica Islandica 9, 9-28.

Edvardsson, R. and Rafnsson, M. 2011. Hvalveiðar útlendinga á 17. öld. Fornleifar á Strákatanga 20052010. Árbók hins íslenzka fornleifafélags 2011, 145-166.

Gardiner, M. and Mehler, N. 2007. English and Hanseatic trading and fishing sites in medieval Iceland: report on initial fieldwork. Germania 85, 385-427.

Georgsson, Á. Ó. 1990. Fornleifaskrá. Skrá um friðlýstar fornleifar. Reykjavík: Pjóðminjasafn Îslands.

Grabowski, M. 2007. Backhäuser und Backöfen in Lübeck. Mitteilungen der Deutschen Gesellschaft für Archäologie des Mittelalters und der Neuzeit 19, 129-136.

Helgason, P. 2018. The Corsair's Longest Voyage. The Turkish Raid in Iceland 1627. Leiden: Brill.

Hofmeister, A. 2000. Hansische Kaufleute auf Island im 15. und 16. Jahrhundert, in A. E. Hofmeister and A. Löhr (eds), Kirche - Kaufmann - Kabeljau. 1000 Jahre
Bremer Islandfahrt, 33-46. Bremen: Staatsarchiv.

Holterman, B. 2018a. The Fish Lands. German trade with Iceland, Shetland and the Faroes in the late $15^{\text {th }}$ and $16^{\text {th }}$ century. Unpublished PhD thesis, Hamburg University.

Holterman, B. 2018b. German merchants at the trading station of Básendar, Iceland. Blog entry, Fish and Ships. https://fishandships.dsm.museum/?p=614

Jónsson, F. 1908. Hinn forni kaupstaður 'at Gásum'. Árbók hins íslenzka fornleifafélags 1908, 3-8.

Köbler, G. 2014. Mittelniederdeutsches Wörterbuch, 3rd edition. Online at https://www.koeblergerhard.de/ mndwbhin.html

Kristjánsson, L. 1983. Íslenskir sjávarhættir, vol. 3. Reykjavík: Bókaútgáfa meningarsjóðs.

Mehler, N. 2000. Die mittelalterliche Keramik Islands. Unpublished Magister thesis, Bamberg University.

Mehler, N. 2004. Die mittelalterliche Importkeramik Islands, in G. Guðmundsson (ed.), Current Issues in Nordic Archaeology. Proceedings of the 21st Conference of Nordic Archaeologists, 6-9 August 2001, Akureyri, Iceland, 167-171. Reykjavík: Mál og mennig.

Mehler, N. 2007. Viking age and medieval craft in Iceland: Adaptation to extraordinary living conditions on the edge of the Old World, in J. Klapste and P. Sommer (eds), Medieval Craft in Rural Landscapes. Ruralia VI, 227-244. Turnhout: Brepols.

Mehler, N. 2015. The sulphur trade of Iceland from the Viking Age to the end of the Hanseatic period, in I. Baug, J. Larsen and S. Samset Mygland (eds), Nordic Middle Ages - Artefacts, Landscapes and Society. Essays in Honor of Ingvild Øye on her 70th Birthday. University of Bergen Archaeological Series 8, 193-212. Bergen: Bergen University Press.

Mehler, N., Kristjánsdóttir, S. and Kluttig-Altmann, R. 2018. The sound of silence - a ceramic horn and its role in monasticism in late medieval Iceland. Early Music 46/4, 551-560.

Möller, G. 2008. Stralsunds mittelalterliches Erbe. Schriftenreihe Stralsunder Denkmale 3, 8-17.

Ólafsson, G. 1980. Fornleifarannsóknir í Gautavík. Ljóri, 1, 24-26.

Ólafsson, G. 1982. Der Ostkomplex, in T. Capelle, Untersuchungen auf dem mittelalterlichen Handelsplatz Gautavík, Island, 60-68. Köln: Rheinland-Verlag.

Ólafsson, G. 2005. Verslunarstaðurinn i Gautavík. Rannsókn á rúst I. Reykjavík: Pjóðminjasafn Îslands.

Olavius, O. 1964. Ferðabók, vol. 1. Reykjavík: Bókfellsútgáfan.

Paulsen, C., Rafnsson, M. and Edvardsson, R. 2008. Foreign Whaling in Iceland. Archaeological Excavations at Strákatangi i Hveravík, Kaldrananeshreppi 2007. Unpublished Data Structure Report. Bolungarvík: Náttúrustofa Vestfjarða.

Rech, M. 2004. Gefundene Vergangenheit. Archäologie des Mittelalters in Bremen, mit besonderer Berücksichtigung von Riga. Bonn: Habelt-Verlag.

Roberts, H. M. 2002. Fornleifarannsókn á Gásum/Archaeological Research at Gásir 2001. An Interim Report/ Framvinduskýrsla. Unpublished excavation report nr. FS163-01071. Reykjavík: Fornleifastofnun Íslands. 
Roberts, H. M. 2003. Gásir 2002. An Interim Report. Unpublished excavation report nr. FS194-01073. Reykjavík: Fornleifastofnun Îslands.

Roberts, H. M. 2005. Excavations at Gásir 2004. An Interim Report. Unpublished excavation report $\mathrm{nr}$. FS280-01076. Reykjavík: Fornleifastofnun Íslands.

Sigurðsson, H. 1978. Kortasaga Íslands frá lokum 16. aldar til 1848. Reykjavík: Bókaútgáfa Menningarsjóðs og pjóðvinafélagsins.

Suchowa, K.-P. 2002. Entwicklungsstufen in der Backofentechnologie. Mitteilungen der Deutschen Gesellschaft für Archäologie des Mittelalters und der Neuzeit 13, 49-50.

Sveinbjarnardóttir, G. 1996. Leirker á Íslandi. Pottery found in excavations in Iceland. Reykjavík: Îslenzka fornleifafélags.

Thompson, M. and Walsh, J. N. 1989. A Handbook of Inductively Coupled Plasma Spectrometry. New York: Springer.

Pór, J. P. 2002. Fornar hafnir á Suðvesturlandi. Reykjavík: Fræðslurit Ferðafélags Îslands.

Porkelsson, M. 2004. Í Hvalfirði: Miðaldahöfn og hlutverk hennar. Unpublished MA thesis, Háskóli Îslands.

porsteinsson, B. and Grímsdóttir, G. Á. 1989. Norska öldin, in S. Líndal (ed.), Saga Íslands IV, 61-258. Reykjavík: Sögufélag.

Porsteinsson, B. and Grímsdóttir, G. Á. 1990. Enska öldin, in S. Líndal (ed.), Saga Íslands V, 3-216. Reykjavík: Sögufélag.

Porsteinsson, B. and Jónsson, B. 1991. Saga Íslands til okkar daga. Reykjavík: Sögufélag.

Traustadóttir, R. and Bolender, D. 2002. Kolkuós i Skagafirði. Forkönnun og rannsóknarácetlun. Hólarannsóknin 2002 - framvinduskýrsla nr. 2. Unpublished excavation report.

Traustadóttir, R. and Einebrant Svenson, J. 2011. Kolkuós $i$ Skagafirði. Framvinduskýrsla 2011. Unpublished report. Hólarannsóknin.

Traustadóttir, R. and Einebrant Svenson, J. 2012. Kolkuós í Skagafirði. Preliminary Excavation Report. Kolkuós 2012. Unpublished report. Hólarannsóknin.

Trigg, H. B., Bolender, D. J., Johnson, K. M., Patalano, M. D. and Steinberg, J. M. 2009. Note on barley found in dung in the lowest levels of the farm mound at Reynistaður, Skagafjörður Iceland. Archaeologia Islandica 7, 64-72.

van der Venne, A. 2008. Poken en stoken, brouwen en koken. Archeologie en geschiedenis van 100 ambachtelijke ovens. Amsterdam: Archeologische Werkgemeenschap voor Nederland.

Vésteinsson, O. 2013. What is in a Booth? Material Symbolism at Icelandic Assembly Sites, in A. Sanmark, S. Semple, N. Mehler and F. Iversen (eds), Debating the Thing in the North I: The Assembly Project, Journal of the North Atlantic, Special Volume 5, 111-124. 